\title{
ERO1-Like Protein Alpha
}

National Cancer Institute

\section{Source}

National Cancer Institute. ERO1-Like Protein Alpha. NCI Thesaurus. Code C114627.

ERO1-like protein alpha ( $468 \mathrm{aa}, \sim 54 \mathrm{kDa}$ ) is encoded by the human ERO1A gene. This protein plays a role in the modulation of both oxidation of and disulfide bond formation in proteins. 